\title{
Replacing cereals with dehydrated citrus pulp in a soybean oil supplemented diet increases vaccenic and rumenic acids in ewe milk
}

\author{
José Santos-Silva, ${ }^{*} \dagger$ Maria T. Dentinho, ${ }^{*}$ Alexandra Francisco, ${ }^{*} \dagger$ Ana P. Portugal, ${ }^{*}$ Ana T. Belo, ${ }^{*}$ \\ António P. L. Martins, $\ddagger$ Susana P. Alves, $\uparrow \S$ and Rui J. B. Bessa† $\S^{1}$ \\ *Unidade Estratégica de Investigação e Serviços em Produção e Saúde Animal-Instituto Nacional de Investigação Agrária e Veterinária \\ (UEISPSA-INIAV), Vale de Santarém, Portugal \\ †CIISA, Centro de Investigação Interdisciplinar em Sanidade Animal, Avenida da Universidade Técnica 1300-477 Lisboa, Portugal \\ ‡Unidade Estratégica de Investigação e Serviços em Tecnologia e Segurança Alimentar-Instituto Nacional de Investigação Agrária e Veterinária \\ (UEISPA-INIAV), Lisboa, Portugal \\ §Faculdade de Medicina Veterinária, ULisboa, Avenida da Universidade Técnica 1300-477 Lisboa, Portugal
}

\section{ABSTRACT}

This study evaluates the effect of the replacement of cereals by dried citrus pulp (DCP) in diets supplemented with $5 \%$ of soybean oil, on ewe milk yield and composition, including milk fatty acid (FA). Four Serra da Estrela multiparous ewes in the second month of lactation were used in a double $2 \times 2$ Latin square design. Ewes were individually penned and milked twice a day with an 8-h interval. Each experimental period included $14 \mathrm{~d}$ of diet adaptation followed by $5 \mathrm{~d}$ of measurements and sampling. The 2 diets included on dry matter basis $450 \mathrm{~g} / \mathrm{kg}$ of corn silage and $550 \mathrm{~g} / \mathrm{kg}$ of either a soybean oil-supplemented concentrate meal containing barley and maize (cereal) or dried citrus pulp (DCP; citrus). Feed was offered ad libitum, considering $10 \%$ of orts, and intake was measured daily. Milk yield was higher and dry matter intake tended to be higher with the citrus diet. Milk composition and technological properties for cheese production were not affected by treatments, except for lactose, which was lower with the citrus diet. Replacement of cereals by DCP resulted in a 3-percentage-point decrease of both 18:0 and cis9-18:1 that were mostly compensated by the 4.19 - and 1.68-percentage-point increases of trans-11-18:1 and cis-9,trans-11-18:2, respectively. The intake of C18 FA tended to increase with the citrus diet compared with the cereal diet, but the apparent transfer of 18:2n- 6 and of 18:3n-3 did not differ between diets. The milk output of C18 FA increased with the citrus compared with the cereal diet, mostly due to the increase of trans-11-18:1 and cis-9,trans-11-18:2 because the daily milk output of 18:0, trans-10-18:1, cis-9-18:1, 18:2n-6 and 18:3n3 did not differ between diets. Replacing cereals with

Received June 15, 2015.

Accepted October 8, 2015.

${ }^{1}$ Corresponding author: rjbbessa@fmv.ulisboa.pt
DCP in an oil-supplemented diet resulted in a selective increase of trans-11-18:1 and cis-9,trans-11-18:2 in milk, with no major effect on other biohydrogenation intermediates.

Key words: dairy ewe, dried citrus pulp, milk fatty acid, biohydrogenation intermediates, soybean oil

\section{INTRODUCTION}

Rumen lipid metabolism, particularly the biohydrogenation of PUFA, is a major determinant of the fatty acid (FA) profile of ruminant milk. Conjugated linoleic acid increase, particularly rumenic acid (cis9,trans-11-18:2) and its precursor vaccenic acid (trans-11-18:1), is one of the main objectives for improving the nutritional value of milk fat (Pintus et al., 2013; Shingfield et al., 2013; Nudda et al., 2014). This goal can be achieved by supplementing ruminant diets with vegetable oils rich in PUFA (Shingfield et al., 2013) among other strategies. However, the nature of the carbohydrates present in these diets influence the rumen biohydrogenation pathways and thus the content of trans-11-18:1 and cis-9,trans-11-18:2 in products. Diets rich in starch and PUFA, particularly 18:2n-6, are frequently associated with changes in the dominant biohydrogenation pathways, markedly increasing the concentration of trans-10-18:1 in fat from ruminant products (trans-10 shift; Aldai et al., 2013; Bessa et al., 2015). In dairy cows, large increases in trans-10-18:1 are often accompanied by a decrease in trans-11-18:1 and cis-9,trans-11-18:2 and reduction of milk fat concentration (Shingfield and Griinari, 2007). Dairy ewes seem less susceptible to the trans-10 shift, although the general pattern is also recognizable (Toral et al., 2010; Gómez-Cortés et al., 2011a,b).

Feeds rich in pectic substances and sugars, such as dried citrus pulp (DCP), can be an alternative to cereals favoring a higher acetic/propionic ratio in rumen, 
and a higher rumen $\mathrm{pH}$ with a small or null effect on productivity (Bampidis and Robinson, 2006). Reports on the effect of dietary replacement of starch by DCP on biohydrogenation-derived FA in milk are limited to dairy cows (Solomon et al., 2000; Elfert et al., 2006; Cabrita et al., 2007). Studies on dairy ewes involving the dietary replacement of starch sources by DCP or other citrus products are scarce (Fegeros et al., 1995; Castrillo et al., 2004; Jaramillo et al., 2009; Shdaifat et al., 2013) and do not report a detailed milk FA analysis. Furthermore, no reports are available about the effects of replacing cereals by DCP in oil-supplemented diets for dairy ewes.

We hypothesized that replacement of cereal by DCP, in a diet providing a large supply of $18: 2 \mathrm{n}-6$, would favor the ruminal trans-11 biohydrogenation pathway to the detriment of the trans-10 shifted pathway, resulting in higher cis-9,trans-11-18:2 and trans-11-18:1 content in milk. Therefore, we conducted a trial to evaluate the effect of the replacement of cereals by DCP in diets supplemented with soybean oil, on the FA composition of ewe milk, particularly on trans octadecenoates and cis-9, trans-11-18:2.

\section{MATERIALS AND METHODS}

\section{Animals, Diets, and Sampling}

Four multiparous Serra da Estrela ewes from the flock of the Polo de Investigação of Fonte Boa, with an average parity of $4.8 \pm 1.26( \pm \mathrm{SD})$ and in the second month of lactation (49 $\pm 7.6 \mathrm{~d}$ after lambing), were used. After weaning at $35 \mathrm{~d}$ in milk, ewes were machine milked twice daily at 0900 and $1600 \mathrm{~h}$. The trial occurred between March and April (2014). The ewes were housed in $3.1-\mathrm{m}^{2}$ individual pens, with permanent access to water. The experimental design consisted of a double $2 \times 2$ Latin square, with 2 diets and 2 sequential experimental periods of $19 \mathrm{~d}$ ( $14 \mathrm{~d}$ of adaptation and 5 $\mathrm{d}$ of data and sample collection). The animal handling followed European Union Directive 2010/63/UE concerning animal care.

The diets contained $450 \mathrm{~g} / \mathrm{kg}$ of corn silage on a DM basis, supplemented with $550 \mathrm{~g} / \mathrm{kg}$ of either a concentrate meal containing barley and maize or DCP as the main energy source. Both experimental concentrates included $50 \mathrm{~g} / \mathrm{kg}$ DM of soybean oil to supply plenty of $18: 2 \mathrm{n}-6$ as a substrate for rumen biohydrogenation pathways. The concentrate feeds were produced by the Feed Compounds for Animal Unit of Polo de Investigação of Fonte Boa. The ingredients and chemical composition of the diets are presented in Table 1. Dried citrus pulp pellets were prepared using orange juice residues, following a conventional industrial process
Table 1. Composition of the experimental diets

\begin{tabular}{lrr}
\hline & \multicolumn{2}{c}{ Diet } \\
\cline { 2 - 3 } Item & Cereal & Citrus \\
\hline Ingredient, g/kg of DM & & \\
Maize silage & 450 & 450 \\
Dried citrus pulp & 0 & 240 \\
Barley & 190 & 0 \\
Maize & 70 & 0 \\
Soybean meal, 48\% & 215 & 235 \\
Soybean oil & 50 & 50 \\
Sodium bicarbonate & 5 & 5 \\
Calcium carbonate & 13 & 13 \\
Salt & 4 & 4 \\
Minerals and vitamins & 3 & 3 \\
Chemical composition, g/kg of DM & & \\
DM & 505 & 497 \\
Ash & 60 & 71 \\
CP & 156 & 167 \\
Ether extract & 76 & 76 \\
NDF & 278 & 300 \\
ADF & 154 & 184 \\
Sugar & 42 & 190 \\
Starch & 377 & 170 \\
Fatty acid, g/100 g of fatty acids & & \\
16:0 & 14.7 & 13.7 \\
18:0 & 4.0 & 4.1 \\
cis-9-18:1 & 23.8 & 23.6 \\
18:2n-6 & 51.2 & 51.6 \\
18:3n-3 & 6.2 & 7.0 \\
\hline
\end{tabular}

that includes pressing with addition of calcium oxide, dehydration of extracted liquor, and its incorporation into DCP (Citricos del Andevalo, S.A., Huelva, Spain). The corn silage and the meal fractions of the diets were manually mixed every day, immediately before distribution to the ewes.

Ewes were weighed at the beginning and at the end of the experimental periods. Feed was offered individually ad libitum, considering $10 \%$ orts, and intake was controlled daily, weighing the amounts of feed offered and refused. Feed samples were collected on a daily basis for chemical analysis to obtain a composite sample of the diets in each period.

Milk production was registered at every milking. Milk samples were collected daily as $10 \%$ of the total volume, obtaining 2 composite samples corresponding to d 15, 16, and 17, and to d 18 and 19 of the experimental periods. Sodium azide solution $(0.8 \%, \mathrm{wt} / \mathrm{vol})$ was used as preservative $(0.05 \mathrm{~g} / \mathrm{L})$, and milk samples were kept refrigerated before processing for composition, technological properties, and fatty acid analysis.

\section{Chemical Analysis}

Feeds were analyzed for DM content (ISO 6496; ISO, 1999), ashes (ISO 5984; ISO, 2002), CP (ISO 5983; ISO, 1997), and ether extract (ISO 6492; ISO, 1999). Neutral detergent fiber, assayed with sodium sulfite, 
without $\alpha$-amylase and expressed with residual ash, and ADF were determined according to Van Soest et al. (1991). Sugar and starch were determined according to Clegg (1956).

The milk was analyzed for fat, protein, lactose, and TS contents (MilkoScan 113B, Foss, Hillerød, Denmark), and pH (Metrohm 713, Herisau, Switzerland). Proportionate samples representing the 2 daily milkings were evaluated for the milk technological properties, assessed by Optigraph (Ysebaert, France), with initial signal set to $7 \mathrm{~V}$, as described by Martins et al. (2009), for the following parameters: clotting time (R), rate of firming (OK20), and curd firmness measures after $20 \mathrm{~min}\left(\mathbf{A}_{\mathbf{2 0 m i n}}\right)$ and $40 \mathrm{~min}\left(\mathbf{A}_{\mathbf{4 0 m i n}}\right)$ of the milk coagulation trial, and after the $2 \times \mathrm{R}\left(\mathbf{A}_{\mathbf{R}}\right)$ and $3 \times \mathrm{R}$ $\left(\mathbf{A}_{2 \mathbf{R}}\right)$ period, which represent suitable cutting time in soft and hard cheese technologies, respectively.

The milk fat layer was isolated by centrifugation for 15 min at $1,000 \times g$ and stored at $-20^{\circ} \mathrm{C}$ until FA analysis. The milk FAME were prepared by the onestep extraction and transesterification method adapted from Molkentin and Precht (2000). Fatty acids were extracted from $50 \mathrm{mg}$ of milk fat with $1 \mathrm{~mL}$ of hexane and $0.2 \mathrm{~mL}$ of potassium hydroxide in methanol. After $3 \mathrm{~min}$ vortexing and $1 \mathrm{~h}$ rest, $100 \mu \mathrm{L}$ of glacial acetic acid were added, followed by $10 \mathrm{~s}$ of vortexing. The liquid phase was removed and transferred to a test tube containing $500 \mathrm{mg}$ of anhydrous sodium sulfate. After 1 min of vortex and 5 min of centrifugation at 1,000 $\times$ $g$, the hexane phase was removed and transferred to a vial for gas chromatography. Fatty acid methyl esters were analyzed using a HP6890A chromatograph (Agilent, Avondale, PA), equipped with a flame-ionization detector and fused silica capillary column (SP-2560, $100 \mathrm{~m} \times 0.25 \mathrm{~mm}$ internal diameter $\times 0.20 \mu \mathrm{m}$ film thickness, Supelco, Bellefonte, PA). The injector and detector temperatures were 250 and $280^{\circ} \mathrm{C}$, respectively. Initial oven temperature of $100^{\circ} \mathrm{C}$ was held for $15 \mathrm{~min}$, increased at $10^{\circ} \mathrm{C} / \mathrm{min}$ to $150^{\circ} \mathrm{C}$ and held for $15 \mathrm{~min}$, increased at $1^{\circ} \mathrm{C} / \mathrm{min}$ to $160^{\circ} \mathrm{C}$ and held for $15 \mathrm{~min}$, and then increased at $1^{\circ} \mathrm{C} / \mathrm{min}$ to $200^{\circ} \mathrm{C}$ and held for $45 \mathrm{~min}$. Helium was used as carrier gas at a flow rate of $1 \mathrm{~mL} / \mathrm{min}$, the split ratio was $1: 30$ and $1 \mu \mathrm{L}$ of sample was injected. Theoretical flame-ionization detector response factors were used to correct peak areas. Milk FA are expressed as a percentage of total FA and as FA yield $(\mathrm{g} / \mathrm{d})$ computed from the FA profile and the milk fat content, assuming that FA compose $93.3 \%$ of milk fat (Glasser et al., 2007).

\section{Statistical Analysis}

Data were analyzed as replicated $2 \times 2$ Latin squares using the Mixed procedure of SAS (SAS Institute Inc.,
Cary, NC). The model included the fixed effects of diet and time and the random effects of square, period, and animal within square. The repeated measures over time within the experimental unit (animal within period) were included in the model as the subject for the repeated statement. For the dependent variables with repeated measures over the 5-d experimental period (i.e., intake, milk yield, and FA yields and balances), covariance structures were tested and selected using both Akaike corrected and Bayesian information criteria after adjusting models using the $\mathrm{AR}(1), \mathrm{ARH}(1)$, ANTE(1), TOEP, TOEPH, CS, CSH, and UN covariance structures. For the dependent variables presenting only 2 repeated measures (i.e., milk composition including FA), UN and CS covariance structures were tested and the best fitting model was selected as described above. Significant differences were considered at the level $P<0.05$. For graphic representation of the relationship between trans-11-18:1 and cis-9,trans-11-18:2 and trans-11-18:1 and trans-10-18:1, simple linear regressions were conducted.

\section{RESULTS}

Ewes' weight variation, intake, and milk production are presented in Table 2. Average BW was $54 \mathrm{~kg}$ for both treatments. Ewes showed a moderate DMI (2.3 and $2.7 \%$ live weight for cereal and citrus diets, respectively) and both DMI and FA intake tended $(P<$ $0.10)$ to be higher with the citrus diet. The citrus diet increased $(P<0.02)$ the intake of $\mathrm{CP}, \mathrm{NDF}$, and sugar and decreased the intake of starch $(P<0.001)$ when compared with the cereal diet. Milk daily yield was higher $(P=0.023)$ with the citrus diet than with the cereal diet. The daily yield in milk solids increased $(P$ $=0.034)$ with the citrus diet as a result of an increase in lactose yield $(P=0.012)$. Feed efficiency did not differ between diets.

Milk composition (Table 3) was not affected by treatments, but fat tended $(P=0.074)$ to increase when cereals were replaced by DCP. The technological properties of milk for cheese production (Table 3) were not affected by dietary treatments.

The replacement of cereals by DCP (Table 4) decreased $(P<0.05)$ the anteiso-15:0, 18:0, cis-9-18:1, and 22:5n-3, proportions in total FA and increased $(P<$ $0.05)$ the $14: 0$, iso-15:0, trans-16:1, trans-11-18:1, trans8,cis-12-18:2, cis-9,trans-11-18:2, trans-11, cis-13-18:2 and trans-9,trans-11-/trans-10,trans-12-18:2 proportions in total FA. Replacement of cereals by DCP resulted in a decrease of 3 percentage points for both 18:0 and cis-9-18:1, mostly compensated by the 4.12 and 1.84 percentage point increase observed for trans-11-18:1 and cis-9,trans-11-18:2, respectively. The 
Table 2. Effect of the diet energy source on nutrient intake, milk yield, and feed efficiency

\begin{tabular}{|c|c|c|c|c|}
\hline \multirow[b]{2}{*}{ Item } & \multicolumn{2}{|c|}{ Diet } & \multirow[b]{2}{*}{ SEM } & \multirow[b]{2}{*}{$P$-value } \\
\hline & Cereal & Citrus & & \\
\hline Live weight, $\mathrm{kg}$ & 54.0 & 54.1 & 8.08 & 0.714 \\
\hline Live weight variation, $\%$ & -0.70 & -2.68 & 0.874 & 0.205 \\
\hline \multicolumn{5}{|l|}{ Intake, $\mathrm{g} / \mathrm{d}$} \\
\hline DM & 1,206 & 1,417 & 134 & 0.065 \\
\hline $\mathrm{CP}$ & 177 & 247 & 28.8 & 0.016 \\
\hline $\mathrm{NDF}$ & 315 & 445 & 51.9 & 0.014 \\
\hline Starch & 459 & 238 & 25.9 & 0.008 \\
\hline Sugars & 32 & 286 & 33.2 & $<0.001$ \\
\hline Starch + sugar & 512 & 504 & 49.5 & 0.832 \\
\hline Fatty acids & 83 & 97 & 9.3 & 0.073 \\
\hline Milk yield, $\mathrm{mL} / \mathrm{d}$ & 708 & 800 & 127 & 0.023 \\
\hline \multicolumn{5}{|l|}{ Milk solids yield, $\mathrm{g} / \mathrm{d}$} \\
\hline Protein & 38.8 & 42.9 & 5.33 & 0.191 \\
\hline Fat & 39.2 & 47.5 & 8.29 & 0.143 \\
\hline Lactose & 39.7 & 43.2 & 6.03 & 0.012 \\
\hline TS & 122 & 139 & 15.2 & 0.034 \\
\hline \multicolumn{5}{|l|}{ Feed efficiency } \\
\hline Milk yield/DMI & 0.588 & 0.601 & 0.094 & 0.653 \\
\hline Milk solids yield/DMI & 0.106 & 0.101 & 0.016 & 0.807 \\
\hline Milk fat yield/FAI ${ }^{1}$ & 0.475 & 0.523 & 0.108 & 0.652 \\
\hline Milk protein yield/CPI & 0.204 & 0.187 & 0.030 & 0.238 \\
\hline
\end{tabular}

ratio trans-10-18:1/trans-11-18:1 did not differ $(P=$ $0.53)$ between diets, reflecting a very large variability mainly due to the fact that, for the citrus diet, one ewe displayed a very large trans-10-18:1/trans-11-18:1 ratio compared with the other 3 ewes (4.35 vs. 0.15 ). The stearoyl-CoA desaturase activity index [cis-9-17:1/ (cis-9-17:1+17:0)] was not affected by treatments $(P=$ $0.46)$.

Intake of $\mathrm{C} 18 \mathrm{FA}$ (Table 5) tended $(P<0.10)$ to be higher with the citrus diet compared with the cereal diet, as a result of the higher intake of 18:0 and 18:3n-3 $(P<0.05)$. Milk output of C18 FA (Table 5) was higher $(P<0.030)$ with the citrus diet compared with the cereal diet, mostly due to the higher output of trans-11-18:1 and cis-9,trans-11-18:2 as the daily milk output of 18:0, trans-10-18:1, cis-9-18:1, 18:2n-6 and 18:3n-3 did not differ $(P>0.10)$ between diets. Apparent transfer of dietary C18 FA into milk was not affected by diets.

\section{DISCUSSION}

In dairy cows, incorporation of DCP (circa 20\% DM) in diets often depresses the DMI (Solomon et al., 2000;

Table 3. Effect of the diet energy source on milk composition and technological traits

\begin{tabular}{|c|c|c|c|c|}
\hline \multirow[b]{2}{*}{ Item } & \multicolumn{2}{|c|}{ Diet } & \multirow[b]{2}{*}{ SEM } & \multirow[b]{2}{*}{$P$-value } \\
\hline & Cereal & Citrus & & \\
\hline \multicolumn{5}{|l|}{ Milk solids, \% } \\
\hline Fat & 5.15 & 6.50 & 1.331 & 0.074 \\
\hline Protein & 5.45 & 5.21 & 0.190 & 0.160 \\
\hline Lactose & 5.39 & 5.32 & 0.098 & 0.247 \\
\hline TS & 17.0 & 17.9 & 1.732 & 0.531 \\
\hline $\mathrm{pH}$ & 6.42 & 6.48 & 0.046 & 0.305 \\
\hline Clotting time $(\mathrm{R})$, min & 10.1 & 11.1 & 1.42 & 0.393 \\
\hline \multicolumn{5}{|l|}{ Curd firmness, ${ }^{1} \mathrm{~V}$} \\
\hline $\mathrm{A}_{\mathrm{R}}$ & 7.19 & 6.90 & 1.190 & 0.356 \\
\hline$A_{2 R}$ & 10.8 & 10.3 & 1.67 & 0.411 \\
\hline $\mathrm{A}_{20 \min }$ & 6.99 & 6.18 & 1.24 & 0.425 \\
\hline $\mathrm{A}_{40 \min }$ & 12.7 & 12.0 & 1.58 & 0.536 \\
\hline Firming rate $(\mathrm{OK} 20)$, min & 9.18 & 9.62 & 1.85 & 0.703 \\
\hline
\end{tabular}

${ }^{1} \mathrm{~A}_{\mathrm{R}}$ and $\mathrm{A}_{2 \mathrm{R}}=$ curd firmness after $2 \times \mathrm{R}$ (clotting time) and $3 \times \mathrm{R}$ (suitable cutting times for soft and hard cheese technologies, respectively); $\mathrm{A}_{20 \mathrm{~min}}$ and $\mathrm{A}_{40 \mathrm{~min}}=$ curd firmness after 20 and 40 min, respectively. 
Table 4. Effect of the diet energy source on milk fatty acid composition (mg/g of total fatty acids)

\begin{tabular}{|c|c|c|c|c|}
\hline \multirow[b]{2}{*}{ Item } & \multicolumn{2}{|c|}{ Diet } & \multirow[b]{2}{*}{ SEM } & \multirow[b]{2}{*}{$P$-value } \\
\hline & Cereal & Citrus & & \\
\hline $4: 0$ & 16.5 & 14.6 & 6.35 & 0.142 \\
\hline $6: 0$ & 17.1 & 16.3 & 1.29 & 0.669 \\
\hline $8: 0$ & 17.5 & 17.4 & 2.39 & 0.945 \\
\hline $10: 0$ & 49.8 & 52.8 & 8.84 & 0.554 \\
\hline $12: 0$ & 29.2 & 30.4 & 4.53 & 0.570 \\
\hline iso-14:0 & 1.2 & 0.7 & 0.31 & 0.141 \\
\hline $14: 0$ & 76.8 & 85.9 & 4.83 & 0.040 \\
\hline iso- $15: 0$ & 1.3 & 1.7 & 0.17 & 0.029 \\
\hline anteiso-15:0 & 3.6 & 2.8 & 0.24 & 0.018 \\
\hline cis-9-14:1 & 1.3 & 1.4 & 0.31 & 0.489 \\
\hline $15: 0$ & 6.2 & 5.8 & 0.68 & 0.060 \\
\hline iso- $16: 0$ & 2.5 & 1.9 & 0.44 & 0.383 \\
\hline $16: 0$ & 225 & 209 & 7.1 & 0.069 \\
\hline trans-9-16:1 & 1.7 & 5.4 & 1.51 & 0.074 \\
\hline iso- $17: 0$ & 3.4 & 3.3 & 0.27 & 0.369 \\
\hline cis-7-16:1 & 2.8 & 2.9 & 0.25 & 0.363 \\
\hline cis-9-16:1 & 7.0 & 6.4 & 0.79 & 0.476 \\
\hline anteiso-17:0 & 3.7 & 2.9 & 0.52 & 0.254 \\
\hline $17: 0$ & 3.7 & 3.6 & 0.23 & 0.787 \\
\hline cis-9-17:1 & 1.3 & 1.3 & 0.18 & 0.757 \\
\hline $18: 0$ & 134 & 103 & 10.1 & 0.008 \\
\hline trans-6/trans-7/trans-8-18:1 & 6.4 & 7.7 & 1.04 & 0.321 \\
\hline trans $-9-18: 1$ & 5.6 & 7.1 & 0.73 & 0.202 \\
\hline trans-10-18:1 & 28.8 & 22.2 & 11.43 & 0.498 \\
\hline trans-11-18:1 & 24.9 & 66.1 & 19.77 & 0.042 \\
\hline trans $-12-18: 1$ & 6.7 & 9.9 & 1.68 & 0.077 \\
\hline cis-9-18:1 & 220 & 188 & 18.8 & 0.011 \\
\hline trans $-15-18: 1$ & 3.9 & 4.9 & 0.33 & 0.107 \\
\hline cis-11-18:1 & 8.6 & 7.9 & 0.98 & 0.194 \\
\hline cis-12-18:1 & 5.2 & 7.8 & 1.21 & 0.138 \\
\hline cis-13-18:1 & 1.2 & 1.6 & 0.19 & 0.071 \\
\hline trans $-16+\mathrm{c} 14-18: 1$ & 4.9 & 5.7 & 0.39 & 0.054 \\
\hline cis-15-18:1 & 1.2 & 1.2 & 0.21 & 0.959 \\
\hline trans-8, cis-12-18:2 & 1.6 & 2.0 & 0.14 & 0.046 \\
\hline cis-9,trans-13-18:2 & 2.4 & 2.7 & 0.26 & 0.339 \\
\hline trans-8, cis-13-18:2 & 1.4 & 1.6 & 0.15 & 0.309 \\
\hline cis -9, trans $-12-18: 2$ & 0.7 & 0.8 & 0.11 & 0.320 \\
\hline cis-16-18:1 & 1.1 & 1.2 & 0.11 & 0.436 \\
\hline trans -9, cis-12-18:2 & 0.6 & 0.6 & 0.15 & 0.754 \\
\hline trans -11, cis $-15-18: 2$ & 1.4 & 1.9 & 0.27 & 0.069 \\
\hline $18: 2 \mathrm{n}-6$ & 43.2 & 36.2 & 11.41 & 0.437 \\
\hline $20: 0$ & 2.4 & 2.2 & 0.22 & 0.317 \\
\hline $18: 3 n-3$ & 4.4 & 4.1 & 1.14 & 0.673 \\
\hline cis-9,trans-11-18:2 & 12.6 & 31.0 & 8.22 & 0.033 \\
\hline trans -9, cis $-11-18: 2$ & 0.50 & 0.52 & 0.062 & 0.821 \\
\hline trans -10, cis- $12-18: 2$ & 0.46 & 0.38 & 0.268 & 0.675 \\
\hline trans-11, cis-13-18:2 & 0.41 & 0.62 & 0.073 & 0.019 \\
\hline trans-11,trans-13-18:2 & 0.16 & 0.25 & 0.039 & 0.070 \\
\hline trans-9,trans-11-/trans-10,trans-12-18:2 & 0.45 & 0.62 & 0.051 & 0.003 \\
\hline $20: 2 \mathrm{n}-6$ & 0.25 & 0.23 & 0.040 & 0.103 \\
\hline cis-9,trans-11, cis-15-18:3 & 0.56 & 0.51 & 0.118 & 0.712 \\
\hline $22: 0$ & 0.93 & 0.98 & 0.082 & 0.701 \\
\hline $20: 3 n-6$ & 0.30 & 0.28 & 0.081 & 0.545 \\
\hline $20: 3 n-3$ & 0.20 & 0.19 & 0.040 & 0.741 \\
\hline $20: 4 n-6$ & 1.8 & 1.6 & 0.19 & 0.269 \\
\hline $20: 5 n-3$ & 0.29 & 0.27 & 0.069 & 0.491 \\
\hline $22: 5 n-3$ & 0.69 & 0.55 & 0.079 & 0.006 \\
\hline $22: 6 n-3$ & 0.38 & 0.36 & 0.047 & 0.793 \\
\hline 10-охо-18:0 & 3.3 & 2.2 & 0.73 & 0.260 \\
\hline trans-10-18:1/trans-11-18:1 & 1.87 & 0.97 & 0.950 & 0.528 \\
\hline $\mathrm{SCD}_{\mathrm{I}}-17^{1}$ & 26.7 & 25.3 & 1.20 & 0.462 \\
\hline SC-SFA $^{2}$ & 211 & 213 & 12.7 & 0.918 \\
\hline SFA & 586 & 558 & 13.1 & 0.185 \\
\hline cis-MUFA & 250 & 220 & 17.9 & 0.026 \\
\hline trans-MUFA & 80 & 122 & 13.5 & 0.005 \\
\hline cis-PUFA & 52 & 44 & 13.5 & 0.424 \\
\hline Total $^{3}$ & 117 & 181 & 21.4 & 0.019 \\
\hline
\end{tabular}

${ }^{1}$ Stearoyl-CoA activity index computed as $[17: 1$ cis-9/(17:1 cis-9 + 17:0) $] \times 100$.

${ }^{2}$ Saturated fatty acid with $14 \mathrm{C}$ or less.

${ }^{3}$ Total of biohydrogenation intermediates. 
Table 5. Effect of the diet energy source on intake, milk output, and apparent transfer of C18 fatty acids to milk

\begin{tabular}{|c|c|c|c|c|}
\hline \multirow[b]{2}{*}{ Item } & \multicolumn{2}{|c|}{ Diet } & \multirow[b]{2}{*}{ SEM } & \multirow[b]{2}{*}{$P$-value } \\
\hline & Cereal & Citrus & & \\
\hline \multicolumn{5}{|l|}{$\overline{\text { Intake, } \mathrm{g} / \mathrm{d}}$} \\
\hline 18:0 & 3.3 & 4.0 & 0.38 & 0.049 \\
\hline cis-9-18:1 & 19.8 & 22.9 & 2.18 & 0.084 \\
\hline $18: 2 n-6$ & 42.7 & 50.2 & 4.77 & 0.063 \\
\hline $18: 3 n-3$ & 5.2 & 6.8 & 0.64 & 0.013 \\
\hline Total C18 UFA ${ }^{1}$ & 67.7 & 80.3 & 7.59 & 0.059 \\
\hline Total C18 & 71.0 & 84.0 & 7.96 & 0.059 \\
\hline \multicolumn{5}{|l|}{ Milk output, g/d } \\
\hline $18: 0$ & 5.1 & 4.3 & 0.64 & 0.107 \\
\hline trans-10-18:1 & 0.95 & 0.91 & 0.238 & 0.885 \\
\hline trans-11-18:1 & 0.93 & 3.03 & 1.121 & 0.013 \\
\hline cis-9-18:1 & 8.1 & 8.1 & 1.38 & 0.984 \\
\hline $18: 2 n-6$ & 1.47 & 1.52 & 0.222 & 0.772 \\
\hline cis-9,trans-11-18:2 & 0.50 & 1.41 & 0.487 & 0.013 \\
\hline $18: 3 \mathrm{n}-3$ & 0.15 & 0.17 & 0.022 & 0.107 \\
\hline Total $\mathrm{BI}^{2}$ & 4.2 & 8.1 & 1.90 & 0.002 \\
\hline Total C18 & 19.1 & 22.7 & 3.46 & 0.030 \\
\hline \multicolumn{5}{|l|}{ Apparent transfer, $\%$} \\
\hline 18:0 & 149 & 118 & 22.1 & 0.138 \\
\hline cis-9-18:1 & 41 & 38 & 7.46 & 0.689 \\
\hline $18: 2 n-6$ & 3.5 & 3.2 & 0.41 & 0.370 \\
\hline $18: 3 n-3$ & 3.0 & 2.6 & 0.40 & 0.236 \\
\hline Total C18 & 27.4 & 28.7 & 4.60 & 0.715 \\
\hline \multicolumn{5}{|c|}{ Milk output/C18 UFA intake, $\%$} \\
\hline trans $-10-18: 1$ & 1.44 & 1.15 & 0.285 & 0.353 \\
\hline trans-11-18:1 & 2.15 & 3.42 & 0.807 & 0.055 \\
\hline cis-9,trans-11-18:2 & 0.99 & 1.66 & 0.375 & 0.035 \\
\hline Total $\mathrm{BI}^{2}$ & 6.6 & 10.5 & 2.11 & 0.034 \\
\hline
\end{tabular}

${ }^{1} \mathrm{C} 18$ unsaturated fatty acids.

${ }^{2}$ Total of biohydrogenation intermediates.

Santos et al., 2014), probably due to increased rumen fill by hydration of DCP on rumen and slightly lower rumen degradation rate of pectin compared with starch as discussed by Santos et al. (2014). Reports on inclusion of DCP replacing cereals in lactating dairy ewe diets are scarce and do not report a depression in DMI (Fegeros et al., 1995; Castrillo et al., 2004; Shdaifat et al., 2013), suggesting that ewes might respond differently from dairy cows. The DMI results observed for citrus diet are coherent with the observed increase in milk yield and total milk solids. Moreover, the crude efficiency ratios of feed to milk and feed to milk solids remained quite similar between diets. Overall, our results indicate that DCP can replace cereals in dairy ewe diets without negative effects on production, as previously reported by others (Fegeros et al., 1995; Shdaifat et al., 2013).

The inclusion DCP in the ewe diet had no effect on milk solid concentration, except for a tendency for a larger fat percentage. Thus, globally our results confirm that the partial replacement of cereals by DCP had no effect on milk composition of dairy ewes (Fegeros et al., 1995).
Ewe milk is used almost exclusively for cheese production and thus milk technological properties are important quality traits to be evaluated. The replacement of cereals by DCP in the diets did not modify the $\mathrm{pH}$, coagulation, and curd firmness parameters that are within the normal range found in Portuguese breeds (Martins et al., 2009).

The supplementation of ewe diets with PUFA sources has been considered a valuable strategy to obtain cheese enriched in trans-11-18:1 and cis-9,trans-11-18:2 with beneficial effects for human health (Pintus et al., 2013). In dairy cows, basal diets with low fiber and high starch and high PUFA content are associated with a shift in rumen biohydrogenation pathways resulting in strong accumulation of trans-10-18:1, to the detriment of trans-11-18:1, as a major biohydrogenation intermediate (Aldai et al., 2013). This trans-10 shift has been related to the milk fat depression syndrome observed more frequently in dairy cows fed high-concentrate diets (Shingfield and Griinari, 2007). Ewes seem to be less sensitive to changes in forage concentrate ratio of basal diet than cows, when lipid supplements are used (Gómez-Cortés et al., 2011a; Nudda et al., 2014). Even 
when fed high concentrate diets, ewes tend to respond to vegetable oil supplementation by largely increasing both trans-11-18:1 and trans-10-18:1 and presenting a trans-10-18:1/trans-11-18:1 ratio below 1 (Toral et al., 2010; Gómez-Cortés et al., 2011a,b). In spite of that, in our experiment, milk from ewes fed the cereal diet presented an average value for the trans-10-18:1/ trans-11-18:1 ratio above 1, suggesting the occurrence of an extensive trans-10-shift in the rumen. Although not usual, this has been reported in literature (GómezCortés et al., 2008b; Szumacher-Strabel et al., 2011).

Up to $89 \%$ of the cis-9,trans-11-18:2 present in milk from ewes fed vegetable oils is derived from endogenous desaturation of trans-11-18:1 catalyzed by stearoylCoA desaturase (Toral et al., 2015). As lipid supplementation of ewes fed a high-concentrate diet increases the trans-11-18:1 availability, it also linearly increases the cis-9,trans-11-18:2 in milk (Figure 1). Nevertheless, a much larger cis-9,trans-11-18:2 concentration in milk should be anticipated if only the trans-11 biohydrogenation pathway was expressed in the rumen. Moreover, the high amounts of trans-10-18:1 in milk fat found in those situations may compromise its nutritional value (Aldai et al., 2013) and may elicit milk fat depression (Toral et al., 2010).

We had hypothesized that the replacement of cereal starch by DCP in oil-supplemented diets would allow a

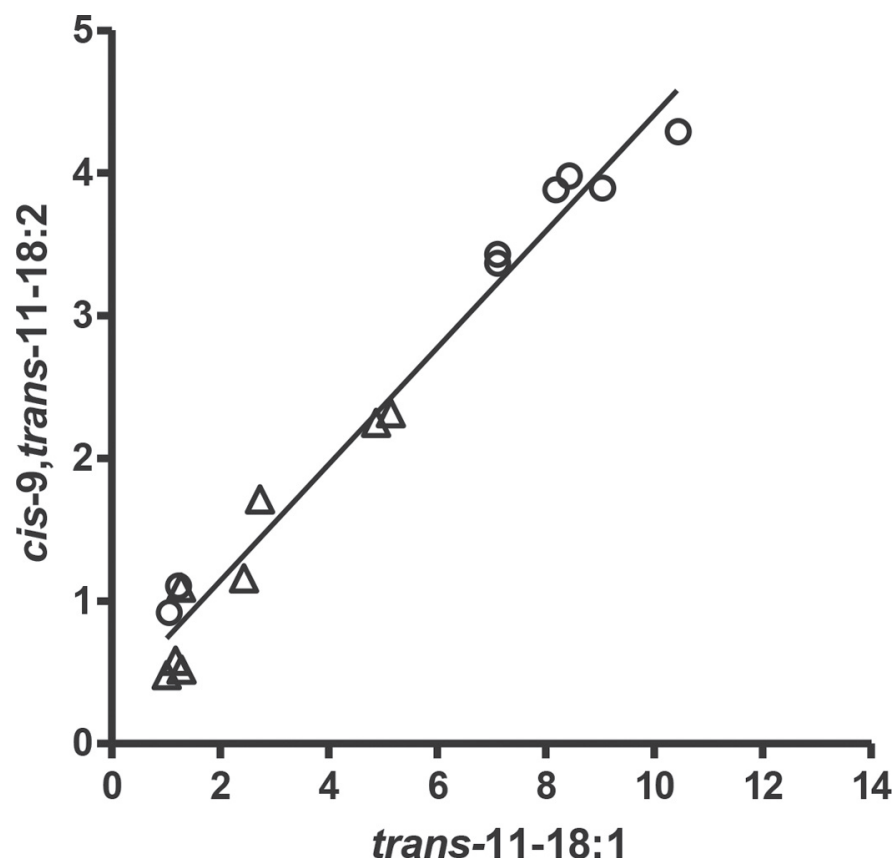

Figure 1. Relationship between trans-11-18:1 and cis9,trans-11-18:2, both expressed in percentage of total milk fatty acids. Data points from cereal $(\Delta)$ and citrus $(\bigcirc)$ treatments. Linear regression: cis-9,trans-11-18:2 $=0.41 \pm 0.017 \times($ trans-11-18:1) $+0.32 \pm$ $0.097, \mathrm{R}^{2}=0.98, P<0.001$. higher cis-9, trans-11-18:2 concentration in milk by preventing the occurrence of trans-10-18:1 production in detriment of trans-11-18:1. Our results partially support our hypothesis, as trans-11-18:1 and cis-9,trans-11-18:2 concentration in milk increased about 2.5 -fold with DCP. However, the increase in trans-11-18:1 and cis9,trans-11-18:2 was not associated with a clear decrease in trans-10-18:1. Similar results have been obtained in dairy cows by Solomon et al. (2000) and Elfert et al. (2006). Solomon et al. (2000) did not report the individualized content of trans-10-18:1 and trans-11-18:1 in milk but observed an increase of cis-9,trans-11-18:2 in milk when about $11 \%$ of corn was replaced by DCP in a diet that included extruded soybean beans. Elfert et al. (2006) replaced totally corn by DCP in diets with $20 \%$ corn and supplemented with $2.25 \%$ of soybean oil and observed no effect on trans-10-18:1 but a 1.5-fold increase in both trans-11-18:1 and cis-9,trans-11-18:2. Thus, our results are quite similar to those reported by Elfert et al. (2006), which used similar DCP inclusion and the same type of lipid supplement. The large response in milk trans-11-18:1 and cis-9,trans-11-18:2 that we observed is probably explained by the larger soybean oil inclusion (2.25 vs. $5 \%$ ) and by the differences in the species used in the trials (ewe vs. cow).

The complete replacement of cereals with DCP seems to increase both trans-11-18:1 and cis-9,trans-11-18:2 mostly by promoting an incomplete biohydrogenation pattern, and by tending to favor the biohydrogenation of $\mathrm{C} 18$ unsaturated FA through the trans-11 pathway, as displayed in Table 5 in which the relation between milk output of C18 FA and intake is shown. High PUFA intake is known to directly increase the amount of biohydrogenation intermediates and thus decrease the completeness of the biohydrogenation but not the extent of biohydrogenation (Harfoot and Hazlewood, 1997). Although the apparent transfer of C18 PUFA is affected by several factors, the major determinant is the extent of its biohydrogenation in the rumen, as discussed in Cabrita et al. (2007). Thus, the C18 unsaturated FA were apparently metabolized to a similar extent in the rumen of animals fed both diets, although in citrus diets a more incomplete biohydrogenation pattern is clear. Replacement of cereals by DCP slightly increased the intake of $\mathrm{C} 18$ unsaturated FA. Thus, the effects of replacing cereals by DCP on milk biohydrogenation intermediates output can be partially explained by increased $\mathrm{C} 18$ unsaturated FA intake.

Plant secondary compounds have been reported to disturb the rumen biohydrogenation pathways and promote the accumulation of biohydrogenation intermediates, presumably by inhibiting the last reductive step (Vasta and Bessa, 2012). Citrus by-products are rich in plant secondary compounds, such as flavonoids and 
phenolic acids (Tripoli et al., 2007; Santos et al., 2014), and their participation on the modulation of rumen biohydrogenation pathways cannot be excluded, as recently discussed by Lanza et al. (2015). These authors replaced barley by DCP in the diet of growing lambs and also found a reduction of 18:0 and an accumulation in biohydrogenation intermediate concentrations in blood plasma, although DCP inclusion increased simultaneously PUFA and plant secondary compound intake, confounding both factors.

As discussed above, previous reports indicate that in dairy ewes, supplementation of high concentrate diets with PUFA-rich oils generally results in an increase in both trans-10-18:1 and trans-11-18:1 in milk (Toral et al., 2010; Gómez-Cortés et al., 2011a,b), which suggests that both fatty acids are positively correlated. Nevertheless, we observed a negative relationship between trans-11-18:1 and trans-10-18:1 (Figure 2) in accordance with the results commonly observed for dairy cows (Shingfield and Griinari, 2007), confirming that a competition between both trans-10- and trans-11-biohydrogenation pathways also occurs in dairy ewes.

Dried citrus pulp has a low content in starch and a high content in pectin but generally is also quite rich in sugars (Bampidis and Robinson, 2006). In fact, the citrus diet contained much lower starch content than the cereal diet, but this was compensated with an increase in sugar content and the intake of starch plus sugar was quite similar between diets. The occurrence of trans-10 shift has been usually related to high-starch, high-oil diets, although much less information is available regarding the effects of sugars. In spite of the very high rumen fermentation rates of sugars, some indications are present that a moderate (5\%) replacement of starch by sugars in dairy cow diets may promote intake, mitigate the milk fat depression and increase NDF digestibility, and support the maintenance of fibrolytic microbial population as reviewed by Firkins (2010). The positive effects of moderate replacement of starch by sugars in high-starch diets can mitigate the trans-10 shift in dairy cows (Martel et al., 2011). Our results support the concept that starch and sugar might exert a quite differential effect on rumen biohydrogenation, probably by protecting the solid associated fibrolytic and biohydrogenating bacteria. In fact, the citrus diet promoted a higher iso-15:0 and lower anteiso-15:0 in milk than the cereal diets, suggesting that it was able to support a higher fibrolytic and solid adherent community than the cereal diet (Fievez et al., 2012).

The results presented are very promising, but some caution is needed due to the reduced number of animals used in the trial and the large individual variability regarding the expression of the trans-10-shift, easily perceived in Figure 2. In fact, 1 in 4 animals

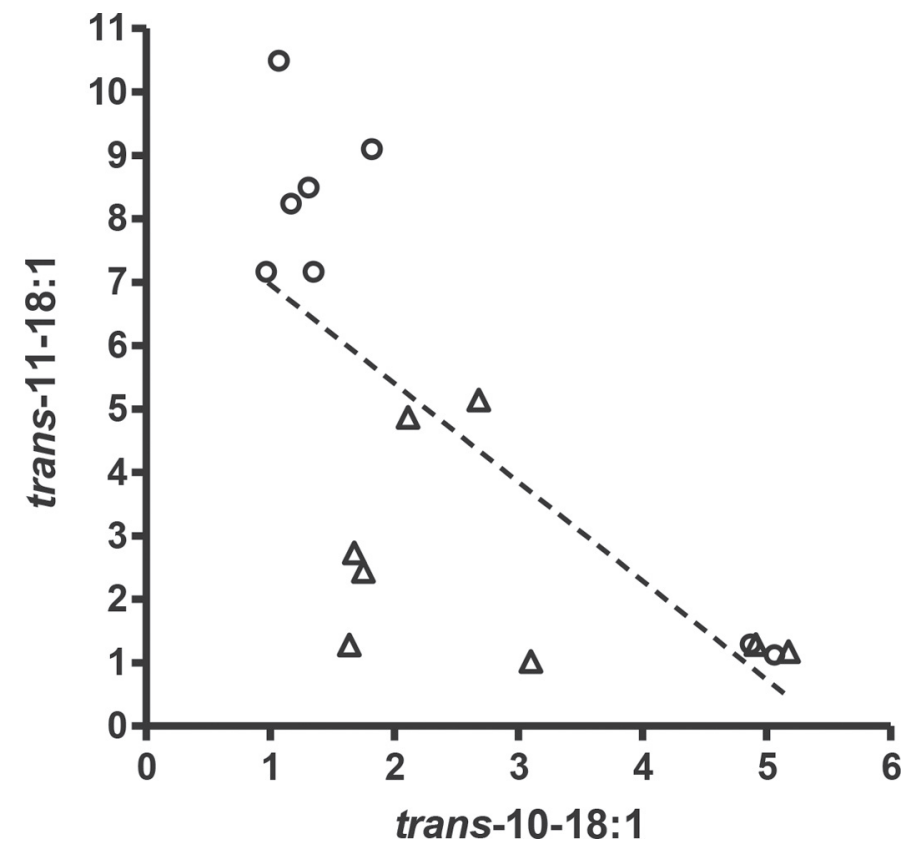

Figure 2. Relationship between trans-11-18:1 and trans-10-18:1, both expressed in percentage of total milk fatty acids. Data points from cereal $(\Delta)$ and citrus $(\bigcirc)$ treatments. Linear regression: trans-10-18:1 $=-1.56 \pm 0.403 \times($ trans $-11-18: 1)+8.52 \pm 1.19, \mathrm{R}^{2}=0.52, P<$ 0.002 .

responded to the citrus diet expressing a large increase of trans-10-18:1 in milk, contrasting with the very large increase of trans-11-18:1 and cis-9,trans-11-18:2 observed in the other 3. Moreover, in dairy ewes, the duration of the feeding period on high-concentrate high-oil oil diets has been reported to modify the relative abundance of trans-18:1 isomers in milk, mostly by a gradual increase in trans-10-18:1 (Gómez-Cortés et al., 2008a, 2011a; Bichi et al., 2013). Our data only considered the average milk FA concentration between d 16 and 19 after the introduction of the diets, so further research is needed to verify if the selective stimulation by the citrus diet of the trans-11-18:1 and cis9,trans-11-18:2 concentrations in ewe milk will persist throughout time.

\section{CONCLUSIONS}

Our data suggest that DCP can be an interesting alternative to cereals in the concentrate fraction of mixed diets for dairy ewes supplemented with vegetable oils. Dried citrus pulp reduces the starch content of the diet, increasing the availability of pectin and sugar as substrates for rumen metabolism, and this seems to favor the trans-11 biohydrogenation pathway in the rumen and the content of trans-11-18:1 and of cis9,trans-11-18:2 in the milk. 


\section{ACKNOWLEDGMENTS}

Financial support through the grant UID/ CVT/00276/2013 and individual fellowships to A. Francisco (SFRH/BD/68773/2010) and S. P. Alves (SFRH/BPD/76836/2011) from Fundação para a Ciência e Tecnologia (Lisbon, Portugal) are acknowledged.

\section{REFERENCES}

Aldai, N., M. de Renobales, L. J. R. Barron, and J. K. G. Kramer. 2013. What are the trans fatty acids issues in foods after discontinuation of industrially produced trans fats? Ruminant products, vegetable oils, and synthetic supplements. Eur. J. Lipid Sci. Technol. 115:1378-1401. http://dx.doi.org/10.1002/ejlt.201300072.

Bampidis, V. A., and P. H. Robinson. 2006. Citrus by-products as ruminant feeds: A review. Anim. Feed Sci. Technol. 128:175-217. http://dx.doi.org/10.1016/j.anifeedsci.2005.12.002.

Bessa, R. J. B., S. P. Alves, and J. Santos-Silva. 2015. Constraints and potentials for the nutritional modulation of the fatty acid composition of ruminant meat. Eur. J. Lipid Sci. Technol. 177:1325-1344. http://dx.doi.org/10.1002/ejlt.201400468.

Bichi, E., G. Hervas, P. G. Toral, J. J. Loor, and P. Frutos. 2013. Milk fat depression induced by dietary marine algae in dairy ewes: Persistency of milk fatty acid composition and animal performance responses. J. Dairy Sci. 96:524-532. http://dx.doi.org/10.3168/ jds.2012-5875.

Cabrita, A. R. J., R. J. B. Bessa, S. P. Alves, R. J. Dewhurst, and A. J. M. Fonseca. 2007. Effects of dietary protein and starch on intake, milk production, and milk fatty acid profiles of dairy cows fed corn silage-based diets. J. Dairy Sci. 90:1429-1439. http://dx.doi. org/10.3168/jds.S0022-0302(07)71628-4.

Castrillo, C., A. Barrios-Urdaneta, M. Fondevila, J. Balcells, and J. A. Guada. 2004. Effects of substitution of barley with citrus pulp on diet digestibility and intake and production of lactating ewes offered mixed diets based on ammonia-treated barley straw. Anim. Sci. 78:129-138.

Clegg, K. M. 1956. The application of the anthrone reagent to the estimation of starch in cereals. J. Sci. Food Agric. 7:40-44. http:// dx.doi.org/10.1002/jsfa.2740070108.

Elfert, E. D. C., R. D. P. Lana, D. P. D. Lanna, W. M. Leopoldino, M. V. M. De Oliveira, P. B. Arcurl, J. M. D. S. Campos, M. I. Leao, and S. D. Valadares. 2006. Effects of different carbohydrates sources and soybean oil on intake, milk yield, and milk composition of lactating dairy cows. Rev. Bras. Zootec. 35:211-218. http://dx.doi. org/10.1590/S1516-35982006000100027.

Fegeros, K., G. Zervas, S. Stamouli, and E. Apostolaki. 1995. Nutritive value of dried citrus pulp and its effect on milk yield and milk composition of lactating ewes. J. Dairy Sci. 78:1116-1121. http:// dx.doi.org/10.3168/jds.S0022-0302(95)76728-5.

Fievez, V., E. Colman, J. M. Castro-Montoya, I. Stefanov, and B. Vlaeminck. 2012. Milk odd- and branched-chain fatty acids as biomarkers of rumen function-An update. Anim. Feed Sci. Technol. 172:51-65. http://dx.doi.org/10.1016/j.anifeedsci.2011.12.008.

Firkins, J. L. 2010. Addition of sugars to dairy rations. Pages 91-106 in Proc. 19th Annu. Tri-State Dairy Nutrition Conf. Ft. Wayne, IN. Pressworks Inc., Plain City, OH.

Glasser, F., M. Doreau, A. Ferlay, and Y. Chilliard. 2007. Technical note: Estimation of milk fatty acid yield from milk fat data. J. Dairy Sci. 90:2302-2304. http://dx.doi.org/10.3168/jds.2006-870.

Gómez-Cortés, P., M. A. de la Fuente, P. G. Toral, P. Frutos, M. Juarez, and G. Hervas. 2011a. Effects of different forage:concentrate ratios in dairy ewe diets supplemented with sunflower oil on animal performance and milk fatty acid profile. J. Dairy Sci. 94:4578-4588. http://dx.doi.org/10.3168/jds.2010-3803.

Gómez-Cortés, P., P. Frutos, A. R. Mantecon, M. Juarez, M. A. de la Fuente, and G. Hervas. 2008a. Milk production, conjugated linoleic acid content, and in vitro ruminal fermentation in response to high levels of soybean oil in dairy ewe diet. J. Dairy Sci. 91:1560-1569. http://dx.doi.org/10.3168/jds.2007-0722.

Gómez-Cortés, P., P. Frutos, A. R. Mantecon, M. Juarez, M. A. de la Fuente, and G. Hervas. 2008b. Addition of olive oil to dairy ewe diets: Effect on milk fatty acid profile and animal performance. J. Dairy Sci. 91:3119-3127. http://dx.doi.org/10.3168/jds.2007-0954.

Gómez-Cortés, P., P. G. Toral, P. Frutos, M. Juarez, M. A. de la Fuente, and G. Hervas. 2011b. Effect of the supplementation of dairy sheep diet with incremental amounts of sunflower oil on animal performance and milk fatty acid profile. Food Chem. 125:644651. http://dx.doi.org/10.1016/j.foodchem.2010.09.053.

Harfoot, C. G., and G. P. Hazlewood. 1997. Lipid metabolism in the rumen. Pages 382-426 in The Rumen Microbial Ecosystem. P. N. Hobson, ed. Elsevier, London, UK.

ISO. 1997. ISO 5983: Animal feeding stuffs-Determination of nitrogen content and calculation of crude protein content-Kjeldhal method. International Organization for Standardization, Geneva, Switzerland.

ISO. 2002. ISO 5984: Animal feeding stuffs-Determination of crude ash. International Organization for Standardization, Geneva, Switzerland.

ISO. 1999. ISO 6492: Animal feeding stuffs-Determination of fat content. International Organization for Standardization, Geneva, Switzerland.

ISO. 1999. ISO 6496: Animal feeding stuffs-Determination of moisture and other volatile matter content. International Organization for Standardization, Geneva, Switzerland.

Jaramillo, D. P., T. Garcia, M. Buffa, M. Rodriguez, B. Guamis, and A. Trujillo. 2009. Effect of the inclusion of whole citrus in the ration of lactating ewes on the properties of milk and cheese characteristics during ripening. J. Dairy Sci. 92:469-476. http://dx.doi. org/10.3168/jds.2008-1293.

Lanza, M., M. Scerra, M. Bognanno, A. Buccioni, C. Cilione, L. Biondi, A. Priolo, and G. Luciano. 2015. Fatty acid metabolism in lambs fed citrus pulp. J. Anim. Sci. 93:3179-3188. http://dx.doi. org/10.2527/jas.2014-8708.

Martel, C. A., E. C. Titgemeyer, L. K. Mamedova, and B. J. Bradford. 2011. Dietary molasses increases ruminal $\mathrm{pH}$ and enhances ruminal biohydrogenation during milk fat depression. J. Dairy Sci. 94:3995-4004. http://dx.doi.org/10.3168/jds.2011-4178.

Martins, A. P. L., A. T. Belo, M. M. Vasconcelos, A. L. Fontes, E. A. Pereira, and C. C. Belo. 2009. Characterisation of production system of Niza cheese (PDO): Effect of sheep breed on milk composition and coagulation properties. Pages 221-225 in Changes in Sheep and Goat Farming Systems at the Beginning of the 21st Century: Research, Tools, Methods and Initiatives in Favour of a Sustainable Development. Options Méditerranéennes: Série A, Vol. 91. P. Morand-Fehr and F. Pacheco, ed. CIHEAM, Zaragoza, Spain.

Molkentin, J., and D. Precht. 2000. Validation of a gas-chromatographic method for the determination of milk fat contents in mixed fats by butyric acid analysis. Eur. J. Lipid Sci. Technol. 102:194-201. http://dx.doi.org/10.1002/(Sici)14389312(200003)102:3<194:Aid-Ejlt194>3.0.Co;2-3.

Nudda, A., G. Battacone, O. B. Neto, A. Cannas, A. H. D. Francesconi, A. S. Atzori, and G. Pulina. 2014. Feeding strategies to design the fatty acid profile of sheep milk and cheese. Rev. Bras. Zootec. 43:445-456. http://dx.doi.org/10.1590/S1516-35982014000800008.

Pintus, S., E. Murru, G. Carta, L. Cordeddu, B. Batetta, S. Accossu, D. Pistis, S. Uda, M. E. Ghiani, M. Mele, P. Secchiari, G. Almerighi, P. Pintus, and S. Banni. 2013. Sheep cheese naturally enriched in alpha-linolenic, conjugated linoleic and vaccenic acids improves the lipid profile and reduces anandamide in the plasma of hypercholesterolaemic subjects. Br. J. Nutr. 109:1453-1462. http://dx.doi.org/10.1017/S0007114512003224.

Santos, G. T., L. S. Lima, A. L. B. Schogor, J. V. Romero, F. E. De Marchi, P. A. Grande, N. W. Santos, F. S. Santos, and R. Kazama. 2014. Citrus pulp as a dietary source of antioxidants for lactating Holstein cows fed highly polyunsaturated fatty acid diets. Asian australas. J. Anim. Sci. 27:1104-1113. http://dx.doi.org/10.5713/ ajas.2013.13836. 
Shdaifat, M. M., F. S. Al-Barakah, A. Q. Kanan, and B. S. Obeidat. 2013. The effect of feeding agricultural by-products on performance of lactating Awassi ewes. Small Rumin. Res. 113:11-14. http://dx.doi.org/10.1016/j.smallrumres.2013.01.014.

Shingfield, K. J., M. Bonnet, and N. D. Scollan. 2013. Recent developments in altering the fatty acid composition of ruminantderived foods. Animal 7:132-162. http://dx.doi.org/10.1017/ S1751731112001681.

Shingfield, K. J., and J. M. Griinari. 2007. Role of biohydrogenation intermediates in milk fat depression. Eur. J. Lipid Sci. Technol. 109:799-816. http://dx.doi.org/10.1002/ejlt.200700026.

Solomon, R., L. E. Chase, D. Ben-Ghedalia, and D. E. Bauman. 2000. The effect of nonstructural carbohydrate and addition of full fat extruded soybeans on the concentration of conjugated linoleic acid in the milk fat of dairy cows. J. Dairy Sci. 83:1322-1329. http:// dx.doi.org/10.3168/jds.S0022-0302(00)74998-8.

Szumacher-Strabel, M., A. Cieslak, P. Zmora, E. Pers-Kamczyc, S. Bielinska, M. Stanisz, and J. Wojtowski. 2011. Camelina sativa cake improved unsaturated fatty acids in ewe's milk. J. Sci. Food Agric. 91:2031-2037. http://dx.doi.org/10.1002/jsfa.4415.

Toral, P. G., G. Hervas, and P. Frutos. 2015. Reductions in milk delta(9)-desaturation ratios to oral dosing of cobalt-acetate are accompanied by the downregulation of SCD1 in lactating ewes. J. Dairy Sci. 98:1961-1971. http://dx.doi.org/10.3168/jds.2014-8731.

Toral, P. G., G. Hervas, P. Gómez-Cortés, P. Frutos, M. Juarez, and M. A. de la Fuente. 2010. Milk fatty acid profile and dairy sheep performance in response to diet supplementation with sunflower oil plus incremental levels of marine algae. J. Dairy Sci. 93:16551667. http://dx.doi.org/10.3168/jds.2009-2769.

Tripoli, E., M. L. Guardia, S. Giammanco, D. Majo, and M. Giammanco. 2007. Citrus flavonoids: Molecular structure, biological activity and nutritional properties: A review. Food Chem. 104:466479. http://dx.doi.org/10.1016/j.foodchem.2006.11.054.

Van Soest, P. J., J. B. Robertson, and B. A. Lewis. 1991. Methods for dietary fiber, neutral detergent fiber, and nonstarch polysaccharides in relation to animal nutrition. J. Dairy Sci. 74:3583-3597. http://dx.doi.org/10.3168/jds.S0022-0302(91)78551-2.

Vasta, V., and R. J. B. Bessa. 2012. Manipulating ruminal biohydrogenation by the use of plants bioactive compounds. Pages 263-284 in Dietary Phytochemistry and Microbes. A. K. Patra, ed. Springer, Dordrecht, the Netherlands. http://dx.doi. org/10.1007/978-94-007-3926-0_9. 